\title{
PARTEC2004 に参加して
}

\author{
空閑 良壽 \\ Yoshikazu Kuga
}

2004 年 3 月 16〜18 日に亘って, ドィッ・ニュル ンベルク市でPARTEC2004 が開催されました。 PARTEC は 3 年ごとにこの時期毎回ニュルンベルク 市のメッセを会場として開催されている粉体工学の 全分野をカバーする国際会議です。個人的には 12 年 前の 1992 年に一度参加した学会です。今回は火炎 法によるナノ粒子合成や粒子生成メカニズム解析で 有名なスイス連邦工科大学チューリッ七校の Prof. Pratsinisがオーガナイザーを務め, ナノテクノロ ジーやエアロゾル関連の分野も充実した会議になるこ とが期待されましたので，久しぶりに参加することに しました。ただし当初は，法人化を迎えた年度末であ り大学内の仕事もいろいろ忙しいことが予測されまし たので, 会議中は少し楽をさせてもらおうということ で, 私の発表はポスターで, オーラルの発表は助手の 藤本氏に任せることとしていました。ところがいざふ たを開けてみると，二人ともセッションの座長を仰せ つかるやら，本誌編集委員長の奥山先生から今回の報 告書の原稿依頼を受けるやらで，(お陰さまで?）た いへん，充実した会議参加となりました。

会議は前日の 15 日から, Registration, ナノ粒子 計測の Workshop が始まり，その日の 18：30から旧 市街内の新博物館で Welcome Reception が開かれま した。ドイツの旧市街はいずれの街も教会や広場があ って似通った様子ですが，それぞれの趣があります (写真 1 )。

さて, Receptionのほうは, 正確な人数は把握して いませんが 400 人以上の参加があったのではないでし ょうか。レセプションの様子は, 現在でも POWTEC 2004 (PARTEC2004 と同時開催) のホームページ （URL $=$ http //www.powtech.de）の中でも見ること ができますように, 飲み物を片手にあちらこちらで親 交を暖めながら進みました。

2004 年 5 月 20 日受付

室蘭工業大学工学部応用化学科

（干050-8585 室蘭市水元町27-1）TEL 0143-46-5765

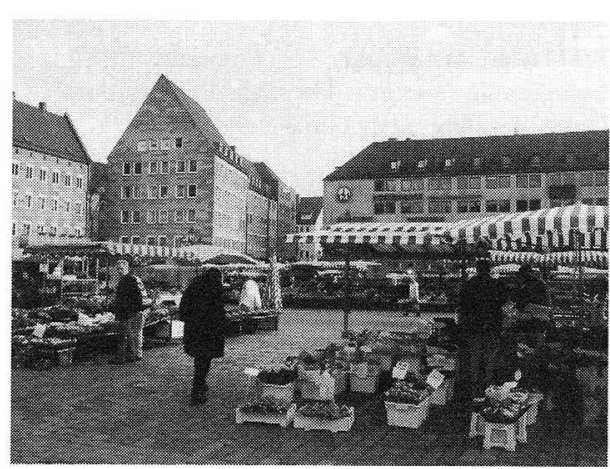

写真 1 ニュルンベルク旧市街の広場

翌日の 16 日, 朝 9:00からニュルンベルク中央駅か ら地下鉄で 10 分程度のところにあるメッセ内の会場 で，会議が始まりました。プログラムは，3 日間にわ たり，午前と午後のセッションのはじまりにPlenary Lecture が 6 件あり，その会場には参加者全員が入れ る大きな部屋が用意されました。最終日の最後の Plenary Lectureでは, 少し空席がありましたが, 毎回多数の参加者が出席し, ほとんど全員が参加して いるといってもよい盛況でした。Plenary Lecture のタイトル，演者を Table 1 に示します。私もすべて の Plenary Lectureを聴かせていただきました。微 粒子が関連するナノテクノロジーにスポットが当てら れ, アカデミックな研究段階から, ナノテク産業, 市 場・商品開発のレベルまで, 様々なレクチャーが用意 されており, 粉体工学, 微粒子工学の分野から本気で ナノテク産業を立ち上げ, 育てていくぞ!という意気 込みが伝わってくるレクチャーが続きました。日本か らは, NEDOのナノテクノロジープロジェクト「ナ ノ粒子の合成と機能化技術」のリーダーをされている 奥山本誌編集委員長の Plenary Lecture が 2 日目の 午前中にあり，活発な討論が行われました（写真 2)。 あいにく私のカメラではご本人の姿はよく映っていま せんが, 多くの聴衆が熱心に耳を傾けているのがおお 
Table 1 List of Keynote Lectures

1. Prof. Hans Leuenberger (U. Basel, Switzerland) Keynote Lecture on Nanocomposites by Spray Freeze Drying

2. Dr. Mike C. Roco

Keynote Lecture on Manufacturing Devices from Nanoparticles

3. Prof. Kikuo Okuyama (U. Hiroshima, Japan) Nanoparticle Project in METI/NEDO's Materials Nanotechnology Program : Recent Research Reviews

4. Prof. Alan W. Weimer (U. Colorado, USA) Commercial Success Through Fundamental Understanding and Persistence

5. Prof. Jim Litster (U. Queensland, Australia) Keynote Lecture on Multiscale Design of Granulation

6. Dr. Andreas Gutsch (Degussa, Germany) Nano-Structured Materials: New Applications and Scientific Demands

かりいただけると思います。これらの Lecturer の人 選には，オーガナイザーの Prof. Pratsinis の尽力が 強く感じとられ，内容的にも中身が濃く，私を含め参 加者にとって大変有意義なものでありました。朝の Plenary Lectureが終ったあと，および午後の口頭 発表の第 1 セッションが終わったあとの 10 時と 15 時 に 30 分間のコーヒーブレイクがあり，この時間にも 発表者, 参加者同志のディスカッションの場が設けら れて親睦を深めることができました（写真 3 )。

その後の一般講演は 5 つの会場に分かれて, 午前, 午後とも 6 件ずつの発表，討論（討論の時間を含めて 1 件 25 分）が行なわれました。さすがにドイツのメ ッセの会場だけあって，どの部屋も広々としていまし たが，参加者も部屋を埋めるに十分に多く，各会場と

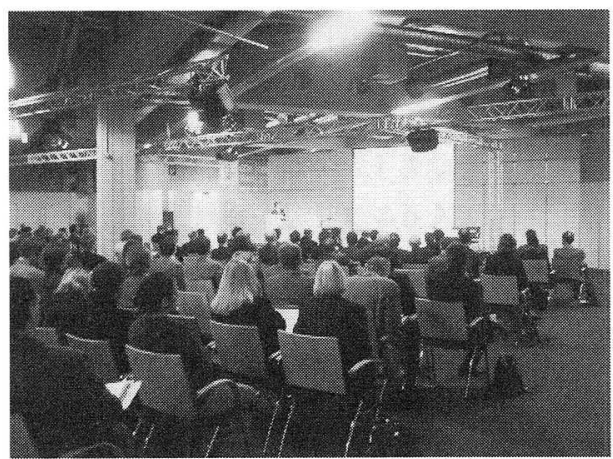

写真 2 奥山本誌編集委員長の Plenary Lecture の様子

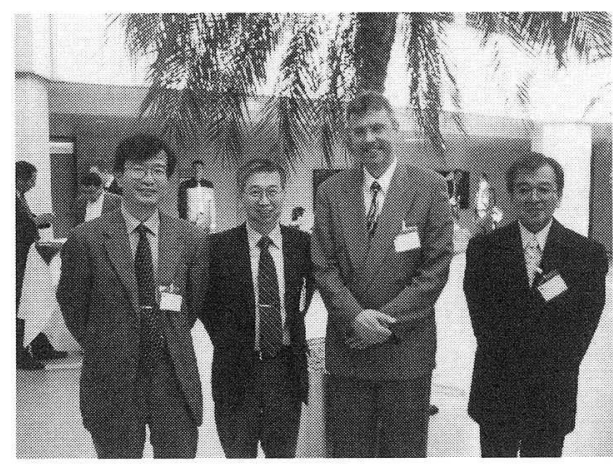

写真3 コーヒーブレイクスペースでのスナップ写真 (左より筆者, 奥山本誌編集委員長, 才ーカ ナイザーの Prof. Pratsinis，川鉄鉱業（株） ・杉辺氏)

もエネルギッシュに活発な発表と討論が行なわれてい ました。これには，事前登録の時点でどのセッション に参加する予定かを知らせることになっており，主催 者側は各セッションのお扰よその参加人数をあらかじ め把握できていたシステムが奏功したと考えられま す。これに基づいて部屋の割り振りが行なわれていた ようです。発表件数はオーラル約 180 件，ポスター発 表 220 件以上，全体で 400 件以上，参加者は 400 人を 超える盛会でした。プログラムの詳細は前述の POWTEC ホームページにてPDFファイルで入手で きます。Table 2 には，各セッションのメインタイト ルだけを示します。(ちなみに私と藤本氏の座長はそ れぞれ最終日の Session27 と23でした。)

1 日目の夕方, $17: 30 \sim 19: 30$ からはポスターセ ッションが始まりました。ポスターは，セッションが 始まる前にはすべて貼り出され，この時間帯にはドィ ッビールを片手にポスターの前で，フランクな質問， 討論が延々と続きました。2 日目の同じ時間帯にも同 様にビールとニュルンベルクバーガーをほおばりなが ら，ポスターセッションが開催され十分なディスカッ ションの時間がありました。今回はベストポスター賞 が設定されており，名前を伏せた覆面の審査員がポス 夕一会場を回り，発表者へ質問等を行い，その受け答 えを採点するなどしてベストポス夕一賞が選出されま した。また，全参加者にも投票用紙が配布されてお り，この投票によってもベストポスター賞を選ぶ仕組 みとなっていました。このようにして最終日の最後の Plenary Lecture の後, Prof. Pratsinis の研究室の学 生, Stavros Tsantilis 氏を初めとする 3 名のベス卜 ポスター賞が発表され，おおいに盛り上がりました。 
Table 2 List of Sessions

\begin{tabular}{ll}
\hline $3 / 16$ \\
\hline 1 & $\begin{array}{c}\text { Optoelectronic Nanoparticles : Indium, Tin \& Zinc } \\
\text { Oxides }\end{array}$ \\
2 & Particle Standards \& New Methods \\
3 & Segregation \& Mixing \\
4 & Life Sciences : Colloids Processing \\
5 & Granular Media \\
6 & Nano : Metals \& Catalysts \\
7 & Shape Characterization \\
8 & Wet \& Dry Grinding \\
9 & Life Sciences : Dispersion \& Rheology \\
10 & Sintering, Coalescence \& Phase Composition \\
\hline
\end{tabular}

\section{$3 / 17$}

11 Nanocomposites

12 Solids Transport

13 Fluidized Beds

14 Life Sciences: Precipitation \& Crystallization

15 Charges \& Particles

16 Nanoparticles by Lasers, Plasmas \& Pyrolysis

17 Bioparticle Characterization

18 Particle Coatings

19 Life Sciences: Pharmaceuticals

20 Filtration

\section{$3 / 18$}

21 Nanocharacterization 1

22 Acoustic Techniques

23 Dynamics of Particle Formation

24 Life Sciences: Agglomeration

25 Adhesion \& Surface-Particle Forces

26 Nanocharacterization 2

27 Cohesion, Humidity Effects \& Aerosol Dilution

28 Silos \& Hoppers

29 Life Sciences: Compaction \& Bio Separations

30 Dust Emission \& Gas Cleaning
また，今回の会議の特徴としては昼休みが 2 時間た っぷりとってあり（もっともヨーロッパの会議はだ いたいこのようなゆったりしたスケジュールかもしれ ません。）ランチの間も出席者同士が親睦を深める機 会がありました。ただし，せっかちな日本人としては オーダーするまでの時間, 料理がでてくるまでの時間 がとても長く感じてしまいましたが…。このお昼休み が長かったもう一つの理由としては, PARTEC2004 と同時開催されていたPOWTECH2004（こちらは, 粉体工学関連の装置, 機械メ一カ一, 大学の研究室 の展示会であり, 日本でいえば粉体工業展や科学装 置機器展に相当するものです。ただし，その規模は POWTECH のほうが数倍以上大きく感じました。）の 展示会を回る時間にあてるということでした。会場の 広さと展示会社，装置の種類を考慮すると，私の場合 はこの昼休みの間だけでは不十分でした。そこで 2 日 目の午後のセッションだけは, 会議を抜けだして展示 会のほうを見て回りました。ホソカワやナラキカイな ど日本企業のヨーロッパ支店の大きな展示ブースもあ り, ナラキカイでは偶然ですが, 室蘭工大の応用化学 科の卒業生, 大和田君が元気に活躍している姿も拝見 でき，嬉しく思いました。

次回の PARTEC は 2007 年の春に, やはりニュル ンベルクで開催予定です。オーガナイザーはニュルン ベルクの隣町にあるエルランゲン・ニュルンベルク工 科大学の Prof. W. Peukert で, 今回にも增して盛会 になるようにと張り切っておられました。今回の日本 からの参加者は私たちを含めても 1 ケ夕の人数にとど まっていたようです。PARTEC は粉体工学分野を幅 広くカバーする国際会議ですし, 次回は日本からの参 加者がもっと増えることを期待します。

\section{正誤 表}

Vol.40 No.11（2003年11月）から Vol.41 No.6（2004年6月）までの誤植等の訂正表を 以下に掲載しました。著者からの申し出, 読者からの指摘によって年間約 2 回に分けて揭 載する予定です。

\begin{tabular}{|c|c|}
\hline 誤 & 正 \\
\hline 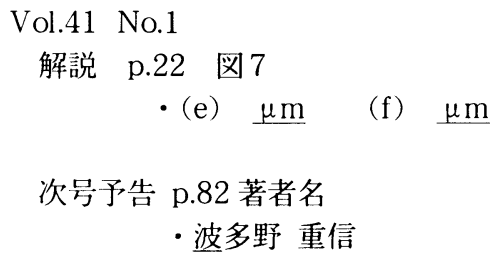 & 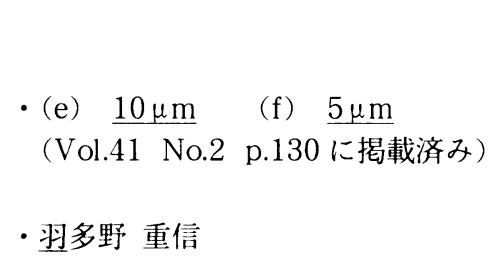 \\
\hline
\end{tabular}

